\title{
Endoscopic Full-Thickness Resection of Colorectal Lesions with the New FTRD System: Single-Center Experience
}

\author{
Susana Mão de-Ferro ${ }^{a}$ Joana Castela ${ }^{a}$ Daniela Pereira $^{b}$ Paula Chaves $^{b}$ \\ António Dias Pereira ${ }^{a}$ \\ ${ }^{a}$ Gastroenterology Department, Instituto Português de Oncologia de Lisboa Dr. Francisco Gentil, EPE, \\ Lisbon, Portugal; b Pathology Department, Instituto Português de Oncologia de Lisboa Dr. Francisco Gentil, EPE, \\ Lisbon, Portugal
}

\section{Keywords}

Full-thickness resection · Colorectal adenomas · Nonlifting lesions

\section{Abstract}

Background and Aims: Endoscopic full-thickness resection (EFTR) is an emerging technique for the treatment of various conditions for which classic endoscopic resection techniques have failed or were considered to be at high risk for perforation. The full-thickness resection device (FTRD) is an over-the-scope system which allows a single-step EFTR. The aim of our study is to describe our experience in EFTR of colorectal lesions using the FTRD. Methods: Nine patients (10 colorectal lesions) were proposed for EFTR. Safety, R0 resection and endoscopic treatment success were evaluated. Results: Reasons for referral included nonlifting adenomas ( $n=4)$, nonlifting adenoma recurrence $(n=5)$, and submucosal lesion $(n=1)$. EFTR was technically successful in all patients. The mean duration of the procedure was $55 \mathrm{~min}$. R0 resection was obtained in all patients. No major complications were detected. All lesions were successfully treated by the endoscopic technique and no patient was referred for

\section{KARGER}

E-Mail karger@karger.com www.karger.com/pjg
(C) 2018 Sociedade Portuguesa de Gastrenterologia Published by S. Karger AG, Basel

Karcer

Open access

This article is licensed under the Creative Commons AttributionNonCommercial-NoDerivatives 4.0 International License (CC BYNC-ND) (http://www.karger.com/Services/OpenAccessLicense). Usage and distribution for commercial purposes as well as any distribution of modified material requires written permission. surgery. In patients with available follow-up $(n=6)$, no recurrence was detected. Conclusions: EFTR is a feasible, reasonable time-consuming, safe, and promising endoscopic resection technique. Key Messages: FTRD is an additional tool for difficult-to-treat colorectal lesions.

(C) 2018 Sociedade Portuguesa de Gastrenterologia Published by S. Karger AG, Basel

\section{Ressecção endoscópica transmural de lesões colorectais com o sistema FTRD: experiência de um centro}

\section{Palavras Chave \\ Ressecção endoscópica transmural · Adenomas colorectais · Adenomas cólicos com sinal de não elevação}

\section{Resumo}

Introdução e objetivos: A ressecção endoscópica transmural (RET) é uma técnica promissora para o tratamento de várias lesões não passíveis de ressecção endoscópica 
pelas técnicas convencionais ou naquelas em que estes procedimentos apresentam elevado risco de complicações. O "full-thickness resection device" (FTRD) é um sistema pré-montado, que se acopla ao colonoscópio e que permite efetuar RET com um procedimento único. Pretende-se descrever a experiência do nosso centro na realização de RET com o FTRD. Métodos: Nove doentes (10 lesões cólicas) foram propostos para RET. Foram avaliadas a segurança, ressecção R0 e taxa de sucesso do procedimento endoscópico. Resultados: As indicações para o procedimento incluíram adenomas $(n=4)$, recidivas de adenomas $(n=5)$ sem elevação após injeção submucosa e lesão submucosa $(n=1)$. A RET foi tecnicamente bemsucedida em todos os doentes. A duração média dos procedimentos foi de 55 minutos. Ressecções R0 em todos os doentes. Não se registaram complicações major. Todas as lesões foram eficazmente tratadas com a ressecção endoscópica e nenhum doente foi proposto para cirurgia. Nos doentes já submetidos a exames de vigilância $(n=6)$ não foram detetadas recorrências. Conclusões: A RET é uma técnica exequível e segura para a terapêutica de lesões coloretais. Mensagens Chave: A RET parece ser uma promissora ferramenta adicional para manejo de lesões colo-rectais difíceis de tratar.

(c) 2018 Sociedade Portuguesa de Gastrenterologia Published by S. Karger AG, Basel

\section{Introduction}

Conventional endoscopic resection techniques, including polypectomy, endoscopic mucosal resection (EMR), and endoscopic submucosal dissection (ESD), are well-known techniques for the treatment of superficial gastrointestinal lesions. They adhere to the basic principles of identification and delimitation of the lesion, submucosal injection to lift the lesion in most techniques, and endoscopic resection of the mucosal and part of the submucosal layer [1].

However, endoscopic resection of colorectal nonlifting lesions, early cancer, and subepithelial lesions may be very demanding or even impossible in some cases [2]. Endoscopic full-thickness resection (EFTR) is an emerging method for minimally invasive resection, which obviates the need for surgical therapy in selected patients. Indications for EFTR include 0-Is or 0-II and selected 0-III [3] colonic lesions with nonlifting sign [4], recurrence of adenomatous lesions resected with conventional endoscopic techniques such as EMR, ESD, or snare polypectomy considered not manageable with a conventional endo- scopic resection technique, lesions located in difficult anatomic sites, such as diverticulum [5] or appendix where the perforation risk during EMR/ESD resection is significant, and subepithelial colonic lesions.

EFTRs are usually performed with a "clip first and cut later technique" in order to close the gut wall before resection, thus preventing perforation. In the first cases described, the lesions were targeted and aspirated into the transparent distal cap, and standard over-the-scope clips (OTSC) were deployed. The pseudopolyps located above the clip were then resected using an oval electrocautery snare [6-8]. The full-thickness resection device (FTRD; Ovesco Endoscopy, Tuebingen, Germany) is an over-thescope system which allows a single-step EFTR after the placement of a modified OTSC [9].

In this report, we present our experience in EFTR of colorectal lesions using the FTRD system.

\section{Patients and Methods}

Data from a prospectively collected database of all patients proposed for EFTR were analyzed. From March 2017 to February 2018 , a total of 9 patients ( 1 of them scheduled for 2 EFTR procedures) underwent colonoscopy for EFTR of colonic or rectal lesions.

The performing endoscopist had undergone a 1-day training in EFTR using the FTRD which included hands-on training on ex vivo pig models prior to the first procedure. All patients provided informed consent to undergo colonoscopy and endoscopic resection with the FTRD technique. Prophylactic antibiotic therapy (cefazoline $1 \mathrm{~g}+$ metronidazole $500 \mathrm{mg}$ ) was instituted immediately before the procedure.

All procedures were performed under deep sedation with propofol under supervision of the anesthesiologist. Intravenous butylscopolamine was given at discretion of the operator to reduce bowel peristalsis. Lesions' removal with the FTRD (Ovesco Endoscopy) was performed following a standardized method [9] (Fig. 1). Initially, the lateral margins of the lesions were marked with coagulation using a FTRD marking probe (Ovesco Endoscopy). Next, the FTRD system was mounted on the colonoscope (Olympus CF-H190L).

The FTRD is a preassembled over-the scope device. A transparent cap with a modified 14 OTSC is mounted over a standard colonoscope. The cap has an inner diameter of $13 \mathrm{~mm}$ and is $23 \mathrm{~mm}$ long. A 13-mm monofilament polypectomy snare is preloaded in the tip of the cap. The snare runs at the outer surface of the endoscope under a plastic sheath. For resection, grasping forceps (Ovesco Endoscopy) are advanced through the working channel of the endoscope to grasp the lesion. The lesion is slowly pulled into the cap to incorporate a double full-thickness layer of the colonic wall. Having the lateral margins of the lesion pulled into the cap, the OTSC is deployed. The pseudopolyp created by the OTSC is then resected with the preloaded snare while the OTSC secures patency of the colonic wall. 




Fig. 1. The FTRD system is presented (www.ovesco.com). 1 Marking of the lesion before mounting the FTRD system. 2 Grasping of the target tissue with the FTRD grasper. 3 Retrieval of the target tissue within cap and fixation. 4 Double check whether the target tissue is completely within the FTRD cap. Release of the clip with handwheel. 5 Closure of the snare and electrical cut of the target tissue. Retrieval of the resected sample. Check of the resection site.
Technical success was defined as reaching the lesion, deploying the clip, and performing an en bloc and macroscopically complete resection.

Clinical success of the endoscopic treatment was defined as R0 resection and histopathology evaluation compatible with adequate endoscopic treatment (lesions with no invasive potential or malignant polyps with no risk factors for lymph node metastasis) [10]. All patients were monitored for at least 1 night after the procedure. Follow-up colonoscopy was scheduled 4-6 months after the initial procedure. All histologic specimens were evaluated by 2 pathologists with gastrointestinal differentiation.

\section{Results}

Ten full-thickness resections were performed in 9 patients $(6$ males, 3 females, mean age 69 years, ranging from 51 to 92 years) (Fig. 2). In patient number 7, both EFTRs were performed the same day. Patients' and lesions' characteristics are described in Table 1.

Lesions were located in the appendix remnant $(n=1)$, ascending colon $(n=1)$, hepatic flexure $(n=1)$, transverse colon $(n=3)$, splenic flexure $(n=1)$, sigmoid colon $(n=$ $1)$, and rectum $(n=2)$. The target lesion was reached with the FTRD and the resection was technically successful in all patients. In 2 patients (patients 1 and 8), there was a tear of the mucosa after OTSC deployment, resulting in the release of the lesion from the grasping forceps. In these cases, the lesions were removed with a conventional 20-mm snare (Olympus SD-230U-20) above the OTSC.

The duration of the procedure ranged from 25 to 80 min (mean duration of $55 \mathrm{~min}$ ). There were no major complications associated with sedation or the endoscopic procedure, including perforation or post polypectomy syndrome. Three patients referred very mild abdominal pain for less than $24 \mathrm{~h}$. One patient presented with selflimiting minor rectal bleeding at the day of the procedure, with no hemodynamic or analytic repercussion and no need for endoscopic hemostasis. The mean hospital stay was 1.4 days (ranging from 1 to 2 days).

Histologic complete (R0) resection was obtained in all patients (Fig. 3). Mean size of the resection specimens was $22.6 \mathrm{~mm}$. Histologic full-thickness resection was obtained in 7 of 10 cases. Full-thickness resection was not possible in patients number 2 and 5 (both presenting rectal lesions) and in patient number 1 that was one of the cases in whom release of the lesion from the graspers occurred during OTSC deployment. The histological examination of the specimens revealed 1 well-differentiated appendicular neuroendocrine tumor (NET G1), 3 adenomas with low-grade dysplasia (tubular: $n=2$; tubulovillous: $n=1$ ), 5 tubular adenomas with high-grade dysplasia, and 1 sessile serrated adenoma. Patient number 3 , 



Fig. 2. EFTR of a nonlifting adenoma recurrence (patient number 4). a White light image: Paris 0-IIa + 0IIc 15-mm lesion with a through-the-scope clip that was placed after mucosectomy due to bleeding. b Narrow-band image (Nice 2) after clip removal. c Lim-

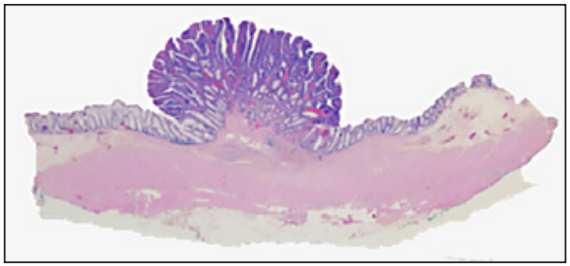

Fig. 3. Histology specimen of a FTRD procedure. Full-thickness resection of a tubulous adenoma with low-grade dysplasia, R0 resection.

with the diagnosis of NET, was staged with CT scan, Gallium-DOTANOC-PET scan, and chromogranin A with no evidence of active diseases and, after multidisciplinary team discussion, surveillance was proposed. Therefore, all lesions were considered to be successfully treated by this technique and no patient was referred for surgery. Follow-up colonoscopy was available in 6 patients and no residual lesion was detected. In 5 of 6 patients, the clips had spontaneously detached from the colonic wall. its were marked with the marking probe. $\mathbf{d}$ Lesion grasping into the cap. e Resection site with the OTSC in situ. $\mathbf{f}$ After 3 months of follow-up.

\section{Discussion}

We present our data on the use of the FTRD system, an all-in-one "first and cut later technique" for EFTR of colorectal lesions. The FTRD system has been marketed in 2014 [9], and the evidence available with this technique is continuously increasing. A multicenter prospective study with 181 patients [11] and a few case series, the largest including 60 patients, have been published so far [1216]. Data show that this technique may offer a simple and reasonable time-consuming procedure for the treatment of various conditions for which classic endoscopic resection techniques, such as EMR and ESD, have failed or were considered to be at high risk for perforation [2]. One difficulty of the technic is advancing the FTRD to the target lesion as the cap with the loaded clip has an outer diameter of $21 \mathrm{~mm}$ and impairs endoscopic vision and flexibility of the endoscope tip.

All procedures were performed successfully, and the duration of the EFTRs in this case series was on average $55 \mathrm{~min}$. This included reaching and marking the lesions, 
Table 1. Patients' characteristics and outcomes following FTRD

\begin{tabular}{|c|c|c|c|c|c|c|c|c|c|c|c|c|c|}
\hline $\begin{array}{l}\mathrm{Pa}- \\
\text { tient } \\
\text { No. }\end{array}$ & Sex & $\begin{array}{l}\text { Age, } \\
\text { years }\end{array}$ & $\begin{array}{l}\text { Reason for FTRD } \\
\text { proposal }\end{array}$ & Location & $\begin{array}{l}\text { Size of } \\
\text { lesion, } \\
\mathrm{mm}\end{array}$ & $\begin{array}{l}\text { Procedure } \\
\text { duration, } \\
\text { min }\end{array}$ & $\begin{array}{l}\text { Size of } \\
\text { specimen, } \\
\mathrm{mm}\end{array}$ & Histology & $\begin{array}{l}\text { R0 re- } \\
\text { section }\end{array}$ & FTR & $\begin{array}{l}\text { Com- } \\
\text { plica- } \\
\text { tion }\end{array}$ & $\begin{array}{l}\text { Sur- } \\
\text { gery }\end{array}$ & Follow-up \\
\hline 1 & M & 73 & $\begin{array}{l}\text { Nonlifting } \\
\text { adenoma relapse } \\
\text { after EMR }\end{array}$ & $\begin{array}{l}\text { Hepatic } \\
\text { flexure }\end{array}$ & 15 & 75 & $17 \times 12$ & $\begin{array}{l}\text { Tubulovillous } \\
\text { adenoma LGD }\end{array}$ & Yes & No & No & No & $\begin{array}{l}6 \text { months, } \\
\text { no recurrence }\end{array}$ \\
\hline 2 & $\mathrm{~F}$ & 79 & $\begin{array}{l}\text { Nonlifting } \\
\text { adenoma relapse } \\
\text { after EMR }\end{array}$ & Rectum & 12 & 47 & $14 \times 12$ & $\begin{array}{l}\text { Tubular } \\
\text { adenoma LGD }\end{array}$ & Yes & No & No & No & $\begin{array}{l}6 \text { months, } \\
\text { no recurrence }\end{array}$ \\
\hline 3 & $\mathrm{~F}$ & 51 & $\begin{array}{l}\text { Submucosal } \\
\text { lesion }\end{array}$ & $\begin{array}{l}\text { Appendix } \\
\text { remnant }\end{array}$ & 12 & 80 & $28 \times 18$ & NET & Yes & Yes & No & No & $\begin{array}{l}12 \text { months, } \\
\text { no recurrence }\end{array}$ \\
\hline 4 & M & 68 & $\begin{array}{l}\text { Nonlifting } \\
\text { adenoma relapse } \\
\text { after EMR }\end{array}$ & $\begin{array}{l}\text { Sigmoid } \\
\text { colon }\end{array}$ & 15 & 50 & $28 \times 22$ & $\begin{array}{l}\text { Tubular } \\
\text { adenoma LGD }\end{array}$ & Yes & Yes & No & No & $\begin{array}{l}4 \text { months, } \\
\text { no recurrence }\end{array}$ \\
\hline 5 & $\mathrm{~F}$ & 67 & $\begin{array}{l}\text { Nonlifting } \\
\text { adenoma relapse } \\
\text { after EMR }\end{array}$ & Rectum & 15 & 25 & $28 \times 20$ & $\begin{array}{l}\text { Tubular } \\
\text { adenoma HGD }\end{array}$ & Yes & No & No & No & $\begin{array}{l}6 \text { months, } \\
\text { no recurrence }\end{array}$ \\
\hline 6 & M & 52 & $\begin{array}{l}\text { Nonlifting } \\
\text { adenoma }\end{array}$ & $\begin{array}{l}\text { Ascending } \\
\text { colon }\end{array}$ & 15 & 70 & $24 \times 22$ & $\begin{array}{l}\text { Tubular } \\
\text { adenoma HGD }\end{array}$ & Yes & Yes & No & No & $\begin{array}{l}6 \text { months, } \\
\text { no recurrence }\end{array}$ \\
\hline $7 \mathrm{a}$ & M & 74 & $\begin{array}{l}\text { Nonlifting } \\
\text { residual } \\
\text { adenoma }\end{array}$ & $\begin{array}{l}\text { Transverse } \\
\text { colon }\end{array}$ & 15 & $40^{\mathrm{a}}$ & $20 \times 20$ & $\begin{array}{l}\text { Tubular } \\
\text { adenoma HGD }\end{array}$ & Yes & Yes & No & No & Scheduled \\
\hline $7 b$ & & & $\begin{array}{l}\text { Nonlifting } \\
\text { adenoma }\end{array}$ & $\begin{array}{l}\text { Transverse } \\
\text { colon }\end{array}$ & 20 & $40^{\mathrm{a}}$ & $23 \times 21$ & $\begin{array}{l}\text { Tubular } \\
\text { adenoma HGD }\end{array}$ & Yes & Yes & No & No & Scheduled \\
\hline 8 & M & 92 & $\begin{array}{l}\text { Nonlifting } \\
\text { adenoma }\end{array}$ & $\begin{array}{l}\text { Ascending } \\
\text { colon }\end{array}$ & 20 & 70 & $20 \times$ & SSA & Yes & Yes & No & No & Scheduled \\
\hline 9 & M & 65 & $\begin{array}{l}\text { Nonlifting } \\
\text { adenoma, } \\
\text { submucosal } \\
\text { invasion? }\end{array}$ & $\begin{array}{l}\text { Splenic } \\
\text { flexure }\end{array}$ & 15 & 50 & $24 \times 19$ & $\begin{array}{l}\text { Tubular } \\
\text { adenoma HGD }\end{array}$ & Yes & Yes & No & No & Scheduled \\
\hline
\end{tabular}

EMR, endoscopic mucosal resection; NET, neuroendocrine tumor; R0, complete resection; FTR, full-thickness resection; LGD: low-grade dysplasia; HGD, high-grade dysplasia; SSA, sessile serrate adenoma. ${ }^{\text {a }}$ Total of $80 \mathrm{~min}$ for the 2 procedures.

mounting the FTRD system on the colonoscope, reaching the lesion with the FTRD, performing the resection, and then reaching the lesion again to re-evaluate the site. In patient number 5 with a rectal adenoma, the procedure took only $25 \mathrm{~min}$. This is in line with what as previously been published. As this is a very small series, we cannot infer if experience may reduce the time to complete the procedure. All lesions were completely resected and in patients for whom follow-up was available, no recurrence was detected. The R0 resection rate with FTRD in published series ranged from 75 to $80 \%[11,13]$.

The median size of the resected lesions was $22.6 \mathrm{~mm}$ which is also similar to what has been previously reported $[11,13]$. The size of the lesions is one of the major problems of the EFTR with the FTRD system, as they are limited by the size of the cap (length $23 \mathrm{~mm}$, inner diameter $13 \mathrm{~mm}$, allowing for a volume of up to $3 \mathrm{~cm}^{3}$ ), lesions' characteristics, and is strongly dependent on the rigidity of the colonic wall. While resection specimens of up to 54 $\mathrm{mm}$ have been reported in experiments with healthy porcine colon [17], all clinical series on EFTR with the FTRD support the removal of lesions with an estimated size of up to $30 \mathrm{~mm}$. However, as has been previously reported, resection success decreased significantly for lesions $>20$ $\mathrm{mm}$. In fact, R0 resection decreased for $58 \%$ for lesions $>2 \mathrm{~cm}$ as compared to $81.2 \%$ for lesions $<2 \mathrm{~cm}$. Therefore, patients' selection is crucial for technical success $[11,13]$. Some hybrid techniques have been proposed to overcome the size problem of the lesions. Hybrid EMR-EFTR consists in the reduction of the size of the lesion with EMR followed by same-day EFTR and seems to be an effective approach for large nonlifting lesions with positive lateral lifting signs [18].

Fischer et al. [19] presented a case report of hybrid polypectomy EFTR. In this case, the volume of the polyp was too large for FTRD resection alone. After partial snare 
polypectomy, full thickness resection of the polyp remnant was performed. The authors suggest that if incomplete snare polypectomy can be expected, additional resection of the polyp base remnant with the FTRD in the same session may be reasonable.

In our case series, no case of invasive cancer was detected and no patient was referred to surgery. Surgery has been proposed to $10-11 \%$ of patients submitted to FTRD, most cases due to carcinoma with noncurative endoscopic resection, unsuccessful technique, or recurrence not amenable to endoscopic therapy. Only $2 \%$ of the patients were referred for surgery due to procedure-related adverse events [11]. We had no major complications and, surprisingly, only a minority of patients presented very mild abdominal pain.

In the first prospective multicenter study on EFTR, procedure-related adverse events were described in up to $10 \%$ of cases. This complication rate is higher than what has been previously described in published case series, but still considered to be acceptable.

Procedure-related events included bleeding, perforation, most of them endoscopically managed, and postpolypectomy syndrome. A case of enterocolonic fistula (probably caused by entrapment of the small bowel in the OTSC) has also been described [11]. Acute appendicitis is also a known complication for EFTR of appendicular lesions and may arise in up to $10 \%$ of cases; most of them are dealt with conservatively.

\section{Conclusion}

We believe that after specific training, EFTR is a feasible, safe, and promising all-in-one endoscopic resection technique and is an additional tool for difficult-to-treat colorectal lesions.

Our data and the data reported in the literature show that EFTR allows complete resection of lesions $<20 \mathrm{~mm}$ with an acceptable risk of adverse events. The FTRD system has some limitations as it only allows the removal of lesions of $<30 \mathrm{~mm}$ and some lesions are difficult to reach with the 21-mm cap. Hybrid EMR-EFTR or polypectomy EFTR and technical modifications of the device may ameliorate these limitations.

\section{Statement of Ethics}

The authors have no ethical conflicts to disclose.

\section{Disclosure Statement}

The authors have no conflicts of interest to disclose.

\section{References}

1 Tanaka S, Kashida H, Saito Y, Yahagi N, Yamano $\mathrm{H}$, Saito $\mathrm{S}$, et al. JGES guidelines for colorectal endoscopic submucosal dissection/ endoscopic mucosal resection. Dig Endosc. 2015 May;27(4):417-34.

2 Mizushima T, Kato M, Iwanaga I, Sato F, Kubo K, Ehira N, et al. Technical difficulty according to location, and risk factors for perforation, in endoscopic submucosal dissection of colorectal tumors. Surg Endosc. 2015 Jan; 29(1):133-9.

3 Participants in the Paris Workshop. The Paris endoscopic classification of superficial neoplastic lesions: esophagus, stomach, and colon: November 30 to December 1, 2002. GastrointestEndosc. 2003 Dec;58(6 Suppl):S3-43.

4 Ishiguro A, Uno Y, Ishiguro Y, Munakata A, Morita T. Correlation of lifting versus nonlifting and microscopic depth of invasion in early colorectal cancer. Gastrointest Endosc. 1999 Sep;50(3):329-33
5 Valli PV, Kaufmann M, Vrugt B, Bauerfeind P. Endoscopic resection of a diverticulumarisen colonic adenoma using a full-thickness resection device. Gastroenterology. 2014 Nov;147(5):969-71.

6 Fähndrich M, Sandmann M. Endoscopic fullthickness resection for gastrointestinal lesions using the over-the-scope clip system: a case series. Endoscopy. 2015 Jan;47(1):76-9.

7 Mönkemüller K, Peter S, Toshniwal J, Popa D, Zabielski M, Stahl RD, et al. Multipurpose use of the 'bear claw' (over-the-scope-clip system) to treat endoluminal gastrointestinal disorders. Dig Endosc. 2014 May;26(3):3507.

8 Al-Bawardy B, Rajan E, Wong Kee Song LM. Over-the-scope clip-assisted endoscopic fullthickness resection of epithelial and subepithelial GI lesions. Gastrointest Endosc. 2017 May;85(5):1087-92.
9 Schmidt A, Damm M, Caca K. Endoscopic full-thickness resection using a novel overthe-scope device. Gastroenterology. 2014 Oct;147(4):740-742.e2.

10 Beaton C, Twine CP, Williams GL, Radcliffe AG. Systematic review and meta-analysis of histopathological factors influencing the risk of lymph node metastasis in early colorectal cancer. Colorectal Dis. 2013 Jul;15(7):788-97.

11 Schmidt A, Beyna T, Schumacher B, Meining A, Richter-Schrag HJ, Messmann H, et al. Colonoscopic full-thickness resection using an over-the-scope device: a prospective multicentre study in various indications. Gut. 2018 Jul;67(7):1280-9.

12 Schmidt A, Bauerfeind P, Gubler C, Damm M, Bauder M, Caca K. Endoscopic full-thickness resection in the colorectum with a novel over-the-scope device: first experience. Endoscopy. 2015 Aug;47(8):719-25. 
13 Valli PV, Mertens J, Bauerfeind P. Safe and successful resection of difficult GI lesions using a novel single-step full-thickness resection device $\left(\right.$ FTRD $\left.^{\circledR}\right)$. Surg Endosc. 2018 Jan; 32(1):289-99.

14 Richter-Schrag HJ, Walker C, Thimme R, Fischer A. [Full thickness resection device (FTRD). Experience and outcome for benign neoplasms of the rectum and colon]. Chirurg. 2016 Apr;87(4):316-25.

15 Aepli P, Criblez D, Baumeler S, Borovicka J, Frei R. Endoscopic full thickness resection (EFTR) of colorectal neoplasms with the Full Thickness Resection Device (FTRD): clinical experience from two tertiary referral centers in Switzerland. United European Gastroenterol J. 2018 Apr;6(3):463-70.

16 Andrisani G, Pizzicannella M, Martino M, Rea R, Pandolfi M, Taffon C, et al. Endoscopic full-thickness resection of superficial colorectal neoplasms using a new over-the-scope clip system: A single-centre study. Dig Liver Dis. 2017 Sep;49(9):100913.

17 Schurr MO, Baur FE, Krautwald M, Fehlker M, Wehrmann M, Gottwald T, et al. Endoscopic full-thickness resection and clip defect closure in the colon with the new FTRD sys- tem: experimental study. Surg Endosc. 2015 Aug;29(8):2434-41.

18 Meier B, Caca K, Schmidt A. Hybrid endoscopic mucosal resection and full-thickness resection: a new approach for resection of large non-lifting colorectal adenomas (with video). Surg Endosc. 2017 Oct;31(10):426874.

19 Fischer A, Knoop RF, Walker C, Thimme R, Richter-Schrag HJ. Resection of a large rectal polyp with the simultaneous combination of snare polypectomy and full-thickness resection device resection. Endoscopy. 2015;47(S 01 Suppl 1):E607-8. 